Красинский Владислав Вячеславович, кандидат юридических наук

Источник публикации: Красинский В.В. Теории «ограниченного суверенитета» и «мирового правительства» в американской политической доктрине // Политический журнал. 2008. № 6-7. С. 56-59; www.krasinskiy.ru

\title{
ТЕОРИИ «ОГРАНИЧЕННОГО СУВЕРЕНИТЕТА» И «МИРОВОГО ПРАВИТЕЛЬСТВА» В АМЕРИКАНСКОЙ ПОЛИТИЧЕСКОЙ ДОКТРИНЕ
}

В ходе праймериз, прошедших в Соединенных Штатах в феврале-марте 2008 г., один из кандидатов на должность Президента США сенатор-республиканец Д. Маккейн заявил о необходимости возвращения к идее единого мирового порядка. Было предложено возродить «демократическую коалицию Запада времен «холодной» войны» с главенствующей ролью Соединенных Штатов - борца за свободу во всемирном масштабе. По мнению Маккейна, новое мироустройство и система безопасности должны обеспечиваться Организацией Североатлантического договора, которая, в отличие от неэффективной $\mathrm{OOH}$, способна предотвращать конфликты, осуществлять контроль за нераспространением оружия массового поражения и оперативно проводить гуманитарные силовые акции. Эти программные заявления «удачно» совпали с активизацией переговорного процесса по размещению элементов ПРО в Европе, расширению НАТО и американским решением проблемы статуса Косова, противоречащим Резолюции СБ ООН от 10 июня 1999 г. № 1244.

Необходимо отметить, что предложенные Маккейном политические идеи оригинальностью не отличаются. Подобные тезисы можно в изобилии встретить на пожелтевших страницах работ 80-х гг. Г. Киссинджера, 3. Бжезинского, Р.Шульца и других, менее известных американских политологов и советологов. В этом нет ничего удивительного, поскольку некоторые из упомянутых деятелей (Г. Киссинджер, Р. Шульц, Д.Вулси) контактировали с предвыборным штабом Маккейна и поддерживают его кандидатуру на предстоящих президентских выборах в США.

Программные установки Маккейна направлены не только на усиление ведущей роли США в международных отношениях, но и затрагивают поиск новых, более утонченных и разнообразных форм поддержания мирового лидерства Соединенных Штатов за счет постепенного и «мягкого» ограничения суверенитета интересующих американское руководство государств.

Несмотря на то, что государственный суверенитет как верховенство и независимость государственной власти внутри страны и за ее пределами является обязательным признаком любого государства, далеко не каждое государство им фактически обладает. В истории известны многочисленные примеры ограниченного суверенитета государств: вассальные государства (Румыния и Сербия до 1878 г., Болгария до 1908 г., индийские княжества до 1947 г); протектораты (Марокко и Тунис до 1956 г.), капитуляции (Турция до 1923 г., Египет до 1937 г., Китай до 1943 г.); подмандатные и несамоуправляющиеся территории (территории, отторгнутые от Германии и Турции в итоге Первой мировой войны и др.). Ограничение государственного суверенитета является одним из традиционных средств расширения сфер влияния государств, претендующих на мировое лидерство. Американская политическая доктрина на протяжении 20-21 вв. является ярким тому подтверждением. Рост экономического могущества, политического, культурного и идеологического влияния США в мире в начале 20 в. способствовал поиску идей, теоретически обосновывающих появление и существование новой мировой империи. А поскольку интересам США противоречило существование региональных державконкурентов, проводящих относительно независимую внутреннюю и внешнюю политику, 
в качестве альтернативы государственным суверенитетам была предложена идея единого «мирового правительства». Эта доктрина, обосновывающая слияние всех государств в единое образование во главе с «мировым правительством», позднее получила известность под названием «мондиализм». Наиболее активную разработку она в различных вариациях приобрела после окончания Второй мировой войны. Весомый вклад в создание теорий ограничения суверенитета и доктрины мирового правительства внесли американские теоретики Бжезинский, Вейгарт, Вилкокс, Гарднер, Дейч, Джессеп, Кларк, Кельзен, Киссинджер, Леви, Мейер, Мерриэм, Митрани, Сон, Спикмен, Фальк, Харрисон, Холл, Эциони и др.

Концептуально доктрина «мирового правительства» основана на координации политики в мировом масштабе и принижении роли суверенных государств в международных отношениях. Создание доминирующего мирового центра под эгидой США является стратегической целью, а многочисленные теории ограничения государственного суверенитета выступают тактическим средством достижения этой цели. Теоретический блок концепций ограничения государственного суверенитета состоит из геополитической, экономической, коммуникативной и юридической составляющих.

Значительная часть теорий «ограничения государственного суверенитета» уходит корнями в геополитику. В работах «Американская стратегия в мировой политике» и «География мира» одного из первых американских геополитиков Спикмена обозначены десять критериев, на основании которых следует определять геополитическое могущество государства. К их числу относятся: 1) территория государства; 2) природа границ; 3) население; 4) наличие полезных ископаемых; 5) экономическое и технологическое развитие; 6) финансовая мощь; 7) этническая однородность; 8) уровень социальной интеграции; 9) политическая стабильность; 10) национальный дух. На взгляд Спикмена, если государство по этим критериям оценивается невысоко, оно должно вступить в общий союз и уступить часть своего государственного суверенитета ради мирового геополитического порядка.

Другие американские ученые (Харрисон, Вейгарт) обосновывали ограничение государственного суверенитета с экономических позиций и увязывали его с лидирующим положением США. Они пытались доказать, что малые страны экономически нежизнеспособны и должны добровольно отказаться от «экономического суверенитета», подчинившись большим державам. Макроэкономическое управление в этом случае должно осуществляться Соединенными Штатами, а малые страны будут выполнять лишь роль поставщиков сырья. Видными представителями экономической составляющей теории ограничения государственного суверенитета являются Гарднер и Митрани. Гарднер возлагал надежду на подчинение США остальной части человечества за счет развитого предпринимательства, определяющего мировой порядок (worldorder business). Митрани в качестве важнейшего фактора мировой интеграции рассматривал контролируемые США международные финансовые институты.

Некоторые американские теоретики (Дейч, Киссинджер, Снайдер) выступают с позиций коммуникативного подхода к обоснованию необходимости ограничения государственного суверенитета и создания мирового правительства. По мнению сторонников данного подхода, одним из основных факторов отрицания государственного суверенитета является межгосударственная взаимозависимость и международные контакты.

Юридическая составляющая теорий «ограничения государственного суверенитета» представлена «теорией международных границ» Холла, теорией «мирового гражданства», теорией компетенции, международно-правовыми теориями Адлера, Джессепа, Кельзена. По мнению Холла, «международная граница» проходит там, где сталкиваются интересы великих держав. Поэтому все территории на Земле входят в сферу верховенства той или иной великой державы. Данная теория использовалась для обоснования создания военных баз США в иностранных государствах. Другой разновидностью юридических теорий 
«ограничения государственного суверенитета» является теория «мирового гражданства». Согласно этой теории государственное гражданство должно быть ликвидировано и заменено единым для всех людей «мировым гражданством». Пропаганда подобных идей направлена на обоснование ликвидации суверенных прав государств по определению правового статуса своего населения. Следующая правовая вариация ограничения государственного суверенитета связана с теорией компетенции. Сторонники данной теории (Кельзен) заменяют территорию государства пространственной компетенцией и утверждают, что в мире не существует территорий, находящихся под исключительной властью одного государства. Особый блок теоретического обоснования ограничения государственного суверенитета составляют концепции некоторых американских юристовмеждународников (Адлер, Джессеп, Кельзен). Суверенитет государства понимается ими исключительно как мотив и предпосылка войн. Отмена государственного суверенитета позволит обеспечить мир на Земле. Вместо конкуренции государств должно быть установлено «господство международного права». Признание принципа верховенства международного права над национальным связывают с именем Кельзена и его трудами «Проблема суверенитета», «Мир с помощью права». Последователи Кельзена выдвинули жесткую альтернативу: либо признавать суверенитет одного государства, исключающий суверенитет других государств, либо отменить государственный суверенитет вообще.

В последних версиях теорий ограничения государственного суверенитета прямо не утверждается о мировом господстве Соединенных Штатов. Данная цель преследуется опосредованно. Например, предлагается реорганизовать ООН и осуществить верховенство права в глобальном масштабе с помощью США. Так что программные заявления Маккейна возникли в 2008 г. не на пустом месте, а являются последовательным выражением американской политической идеологии «ограниченного суверенитета».

Как уже отмечалось, многие теории ограничения государственного суверенитета призваны обслуживать концепцию «мирового правительства», а мировое правительство, в свою очередь, должно стать средством осуществления политики США. Доктрина мирового правительства предусматривает формирование мировой системы финансового контроля, единое мировое законодательство, международную конституционную юстицию, создание наднациональных организаций и надгосударственных образований (Бжезинский, Кларк, Мерриэм, Сонн, Эциони). Первые попытки практического воплощения доктрины мирового правительства относятся к двадцатым годам XX века. В 1921 г. с целью создания мировой системы финансового контроля, предназначенной для управления глобальными политическими и экономическими процессами, был учрежден Совет по международным отношениям (Council on Foreign Relations). В 1937 г. в США начала свою деятельность первая организация (International Campaign for World Government), основной целью которой было формирование мирового правительства. В ноябре 1945 г. к работе приступил комитет по созданию Всемирного правительства, который к 1948 г. подготовил первый проект всемирной конституции (вошедший в историю как «чикагский проект», поскольку 6 из 9 составителей всемирной конституции были преподавателями Чикагского университета). Чикагский проект описывал всемирную федеративную президентскую республику. Президент всемирного государства наделялся не только исполнительными, но и судебными полномочиями в качестве Верховного судьи и председателя Верховного суда. Предусматривалось создание вооруженных сил всемирной республики. Контроль за ними передавался одной из палат всемирного федерального собрания - палате наблюдателей под председательством Президента. Провозглашался один мировой язык. В 1954 г. образован Бильдербергский клуб, занимающийся планированием и координацией деятельности олигархических структур в различных странах мира. В 1973 г. Советом по международным отношениям была создана Трехсторонняя комиссия (Trilateral Comission) по урегулированию широкого спектра вопросов взаимодействия американской, европейской и тихоокеанской экономических зон. Одним из этапов на пути реализации глобальной американской стратегии создания 
мирового государства стало оформление политической компоненты Европейского Союза. Таким образом, теоретическая доктрина «мирового правительства» и «нового мирового порядка» превратилась в реальность.

Конец XX века ознаменовался ликвидацией двухполюсной глобальной системы. В связи с устранением Советского Союза безоговорочное доминирующее экономическое, военно-политическое и идеологическое положение в мире стали занимать Соединенные Штаты. Как отмечает Бжезинский в работе «Великая шахматная доска», американское мировое превосходство породило новый международный порядок, который воспроизводит черты американской политической системы: систему коллективной безопасности (НАТО, Американо-японский договор о безопасности); региональное экономическое сотрудничество (AРEC, NAFTA) и специализированные глобальные организации (Всемирный банк, МВФ, ВТО); демократическое членство в ключевых союзах и процедуры совместного принятия решения при доминировании Соединенных Штатов; глобальную систему конституционной юстиции.

По мнению Бжезинского, «в случае сознательного или непреднамеренного отказа Америки от своего статуса единственной сверхдержавы реальной альтернативой американскому лидерству в обозримом будущем может быть только анархия в международном масштабе». Хотите Вы это или нет, Америка несет ответственность за судьбы мира и устанавливает правила поведения для всех остальных государств. «Америка стоит в центре взаимосвязанной вселенной, такой, в которой власть осуществляется через постоянное маневрирование и стремление к формальному консенсусу, хотя эта власть происходит в конце концов из единого источника, а именно: Вашингтон, округ Колумбия. И именно здесь должны вестись политические игры в сфере власти, причем по внутренним правилам Америки». Приведенная цитата Бжезинского содержит весьма откровенное выражение сути мондиалистской модели мирового устройства, согласно которой «мировое правительство» становится единственным центром власти, а суверенной является только империя «нового мирового порядка». Следует согласиться с А. Дугиным («Основы геополитики»), что принятие такой модели исключает любой суверенитет, так как все части мировой империи (за исключением Центра) становятся колониями.

Американское глобальное доминирование и политика ограничения отдельных государственных суверенитетов сложились не за один день. Этот результат стал закономерным следствием мирового политического развития в XX веке и системного взаимодействия экономических, политических и идеологических факторов. В числе экономических факторов, способствующих укреплению гегемонии США, можно назвать: долларизацию значительной части национальных экономик, привязку мировых цен на сырье к американской валюте, предоставление контролируемыми США финансовыми институтами кредитов отдельным странам, льгот в области торговли, налогообложения, таможенных сборов под условиями проведения определенных реформ, выгодных американской администрации, портфельные инвестиции американских кампаний и частных лиц в национальные экономики и отрасли, установление экономических санкций за сотрудничество с отдельными государствами, стремящимися проводить независимую от Вашингтона политику, искусственное поддержание экономической отсталости ряда государств за счет ограничения их в доступе к передовым технологиям и разработкам, навязывание кабальных экономических проектов. К политическим факторам относятся: принятие важнейших политических решений на форумах ограниченного состава под председательством США, осуществление односторонних военных акций, нарушающих нормы международного права, монополия на миротворческую деятельность в ряде регионов мира, легитимация Соединенными Штатами результатов выборов, проходящих в мире, избирательное использование международно-правового института признания государств в качестве инструмента проведения внешней политики, участие США в законодательной деятельности иностранных государств, принятие Конгрессом США 
законов для других стран мира, требования к иностранным государствам об экстрадиции, противоречащие национальному законодательству этих стран, игнорирование судебных иммунитетов иностранных государств, незаконное обращение взысканий на имущество иностранных государств, экстерриториальность и неподсудность американских военнослужащих и гражданского персонала, обслуживающего военные базы США за границей. Идеологические факторы доминирования Соединенных Штатов в глобальном масштабе представлены: международным характером английского языка, монополией американских информационных агенств и СМИ на формирование и распространение информации в мире, стимулированием отъезда в США высококвалифицированных специалистов, ученых, деятелей культуры и искусства, ускорением научно-технического, технологического и информационно-телекоммуникационного отрыва Соединенных Штатов от других государств мира.

Особого комментария с точки зрения ограничения государственных суверенитетов заслуживают участие США в законодательной деятельности иностранных государств и принятие Конгрессом США законов для других стран мира.

В законотворчестве иностранных государств, представляющих интерес для Соединенных Штатов, главное внимание уделяется таким приоритетным сферам правового регулирования, как порядок организации и проведения выборов органов государственной власти, судоустройство и охрана правопорядка, деятельность неправительственных организаций, СМИ, свобода вероисповедания. Так, в преддверии выборов в Армении 2007-2008 гг. Соединенные Штаты поддержали разработку и модернизацию избирательного законодательства Республики Армения. В Комитет Государственной Думы Федерального Собрания РФ по делам религии Агенством США по международному развитию вносились предложения об изменении федеральных законов, регулирующих свободу вероисповедания и религиозную деятельность в России. Аналогичные призывы о пересмотре законов поступали от США Узбекистану, Казахстану и руководству ряда др. государств - участников СНГ.

Нужно отметить, что США являются единственным государством, которое не только помогает национальным парламентам принимать внутригосударственные законодательные акты, отвечающие стратегическим интересам американской демократии, но и само принимает законы для других стран мира. Примером распространения юрисдикции Соединенных Штатов в отношении других государств является Закон о свободе вероисповедания в странах мира от 27 января 1998 г., Закон о демократии в Беларуси от 20 октября 2004 г.

Закон о свободе вероисповедания в странах мира 1998 г. предписывает проведение Соединенными Штатами ежегодного анализа положения дел со свободой вероисповедания во всем мире и определение стран, которые «совершили или допустили особенно серьезные нарушения свободы вероисповедания» в отчетный период. После включения какого-либо государства в список «стран, вызывающих особую озабоченность» Государственный секретарь США принимает решение о том, какие действия (в том числе санкции) следует предпринять в отношении данной страны. Аналогичную политико-правовую природу имеет Закон о демократии в Беларуси 2004 г, предусматривающий помощь белорусским политическим партиям, неправительственным организациям и независимым СМИ и устанавливающий запрет правительственным агентствам США на предоставление кредитов и инвестиций правительству Беларуси.

Однако распространением свободы во всем мире роль Америки как крестоносца демократии не исчерпывается. По мнению Государственного департамента США, «свободные государства еще должны подтвердить свою полную приверженность демократическому процессу». Иначе опять возникает риск попасть в «черный список стран оси зла» - под лазерные прицелы высокоточного оружия. Хотя внешне все выглядит вполне миролюбиво: «цель политики США должна без каких-либо оправданий состоять из двух частей: необходимости закрепить собственное господствующее положение и 
необходимости создать геополитическую структуру, которая будет способна смягчать неизбежные потрясения и напряженность, вызванные социально-политическими переменами, в то же время формируя геополитическую сердцевину взаимной ответственности за управление миром без войн». Теоретически сложно возразить 3. Бжезинскому. А как на практике выглядит «политика управления миром без войн» мы с вами уже знаем. Бомбардировки Судана и Югославии, вторжение контингентов вооруженных сил США и блока НАТО в Афганистан и Ирак наглядно продемонстрировали заявленный миролюбивый характер.

Настойчивые попытки американского руководства удержать доминирующее положение Соединенных Штатов в качестве мирового лидера вполне объяснимы, если проанализировать, какие возможности предоставляет выборочное и «мягкое» ограничение отдельных государственных суверенитетов Америке.

С точки зрения экономики принижение роли суверенных государств во имя доминирующего мирового центра под эгидой США дает: форсирование вывоза капитала, приобретение (расширение) рынков сырья (в первую очередь, энергоносителей) и сбыта продукции, облегчение выноса экологически опасных производств и отраслей из США.

С точки зрения политики: формирование во всех регионах мира проамериканских политических режимов с контролируемой системой органов государственной власти и отвечающей национальным интересам США системой законодательства, размещение военных баз во всех стратегических районах земного шара; формирование новой системы международного права, ориентирующейся на потребности Соединенных Штатов и предоставляющей Америке исключительные преференции.

С точки зрения идеологии: формирование в общественном сознании ощущения безграничного превосходства американской науки, культуры и искусства, распространение мировоззренческих ценностей американского образа жизни, консолидация американского общества по внешнеполитическим вопросам, затрагивающим национальные интересы США.

C точки зрения социальной сферы: направление на социальные программы Соединенных Штатов денежных средств, полученных за счет снижения издержек производства, вывоза капитала в другие страны, гибкое сдерживание внутреннего потребления и роста жизненного уровня населения.

К чему приводило ограничение государственных суверенитетов для потерпевшей стороны всем известно. Унизительные условия Версальского мирного договора для Германии послужили одной из причин Второй мировой войны. Мюнхенская конференция 1938 г., на которой представителям Чехословакии не было позволено обсуждать принятые в итоге решения, привела к уничтожению Чехословацкого государства. Показательные гуманитарные бомбардировки Югославии в 1999 г. повлекли за собой изгнание более 200 тысяч сербов из провинции Косово-Метохия и отторжение края в 2008 г. Гуманитарная оккупация Ирака под предлогом поиска оружия массового поражения вызвала всплеск непрекращающегося насилия и терроризма... Какие примеры еще нужно привести для того, чтобы доказать недопустимость принижения роли суверенного государства и произвольного вмешательства во внутренние дела! Зачем перечеркивать действующее международное право, в соответствии с которым распространение власти одного государства на территории другого государства допускается лишь в исключительных случаях и только при добровольном разрешении и согласии последнего в пределах, установленных этим государством?

Поэтому любые попытки Д. Маккейна и его сторонников внедрить в международное право и межгосударственную практику теории «ограниченного суверенитета» в целях оправдания защиты демократии с помощью односторонних силовых акций НАТО в обход Совета Безопасности ООН недопустимы. Замена функций ООН военными операциями НАТО приведут человечество к катастрофическим последствиям. Предложения сенаторареспубликанца Д. Маккейна построить на основе НАТО новый мировой порядок по- 
американски и юридически оформить его представляют непосредственную угрозу и для России. По большинству параметров современные политические и военные установки НАТО (расширение блока за счет Украины и Грузии, развертывание третьего позиционного района системы ПРО в Европе, принятие новой стратегической концепции HАТО, предусматривающей ведение силовых операций вне зоны действия Вашингтонского договора без санкции СБ ООН и др.), противоречат интересам безопасности Российской Федерации. Как представляется, современная система международной безопасности и практика межгосударственных отношений должны базироваться не на конфронтационных подходах «холодной войны», а на принципах уважения суверенитета, независимости и взаимовыгодных отношениях государств в международных делах.

Красинский Владислав Вячеславович кандидат юридических наук, эксперт Российского общественного института избирательного права (РОИИП)

Источник публикации: Красинский $B . B$. Новый империализм. Теории «ограниченного суверенитета» и «мирового правительства» в американской политической доктрине // Политический журнал. 2008. № 6-7. С. 56-59. 